\title{
分布型土研モデルによる \\ 合流式下水道の雨天時污濁負荷流出解析 \\ A DISTRIBUTED RUNOFF SIMULATION MODEL OF WATER QUALITY IN COMBINED SEWER PIPE SYSTEMS
}

\author{
永吉光一 1 . 石田和広 $2 \cdot$ 渡辺政広 ${ }^{3} \cdot$ 李 $大 民 4$ \\ Koichi NAGAYOSHI, Kazuhiro ISHIDA, Masahiro WATANBABE and Daimin RI \\ 1正会員 工修 日本上下水道設計㑣東京支社 関東事務所（テ338-0012 さいたま市中央区大戸4-26-8） \\ 2 正会員 株式会社キク）コンクリート製品事業部（テ790-0067 松山市大手町1-7-3） \\ 3正会員 工博 愛媛大学教授 工学部環境建設工学科（テ790-8577 松山市文京町3） \\ 4 学生会員 愛媛大学大学院理工学研究科博士前期課程 環境建設工学専攻（テ790-8577 松山市文京町3)
}

\begin{abstract}
Owing to overflows form combined sewer pipe systems, water quality of receiving waters, including urban rivers, in Japan, has been become worse year by year. Therefore, appropriate counter-measures that can mitigate the overflows must be developed promptly. In order to achieve this, a distributed simulation model of water quality and stormwater runoff is investigated, which can simulate precisely both open-channel and surcharged flows and a temporal and spatial variation of runoff-water quality in the pipe systems.

The model proposed here consists of two well-known models: one is PWRI (the Public Works Research Institute, the Ministry of Construction, Japan) Model for water quality simulations; the other is MOUSE Model for stormwater runoff simulations.
\end{abstract}

Key Words : distributed model, PWRI model, combined sewer pipe system, water quality, runoff simulation model

\section{1.はじめに}

各地の合流式下水道流域で，下水道管渠システムから の越流水（未処理放流水）を軽減・防止する対策の検討 が進められてきているが，合理的で有効かつ実用的な対 策を立案するためには，下水道流域における雨天時の污 濁負荷流出を精度高くシミュレートできる流出解析モデ ルが必要となってくる.

そうした解析モデルとして, 近年, SWMM モデル, MOUSE モデル, InfoWorks モデルなどのいわゆる海外 モデル1)が広く利用されるようになってきている。これ は, わが国で既に開発されている唯一の解析法である, 土研モデルと修正RRL法を組み合わせた流出解析法では, 所要の精度で雨水・污濁負荷流出解析を遂行することが 困難であるためで，それら海外モデルが優れた污濁負荷 流出解析のサブ・モデルを備えているためだけではない と考えられる.
著者らは，わが国で 1980 年の頃に開発された土研モ デル（集中型土研モデル） ${ }^{2)}$ は実用性が極めて高く，優 れた污濁負荷流出解析モデルであることを害証的立場か ら明らかにしてきている(3) 5) が，ここでは，本モデル を, 各種越流水対策の効果を正確に評価しえる精度の流 出シミュレーションが可能なモデルへと改良した分布型 土研モデルを提案するとともに，本モデルを低平市街地 の一ポンプ排水区に適用し，シミュレーション結果と実 測結果を対比して分布型土研モデルの実流域における適 用性を検討している.

なお，集中型モデルから分布型モデルへと改良を図っ た主要な点は, 以下の 3 つである.

(1)地表面上および下水管渠システム内の污濁負荷流出 は，従来，集中化して取り扱われていたが，これを，上 流マンホール，1 本の下水管渠およびその集水域からな る小排水区の単位で取り扱えるよう改良を図った.

(2)污濁の流出は, 従来, 掃流による（污濁は粒子性で ある）として取り扱われていたが，浮遊による流出も存 在している（溶解性の污濁も存在している）筈で, 掃流 
と浮遊による流出を取り扱えるよう改良を図った。

(3)上の(1)により, 組み合わせて用いられる雨水流出モ デルとして，たとえば，上述した海外モデルが利用でき るよう改良が図られたことになる。

\section{2. 合流式下水道の雨天時污濁負荷流出解析}

\section{モデル}

提案している合流式下水道の雨天時污濁負荷流出解析 モデルは, 図-1 に示すように, 流域モデリング, 雨水 損失モデル, 雨水流出モデル, 污濁負荷流出モデルの 4 つのサブ・モデルから構成されている.

\section{（1）流域モデリング}

流域が多数の単位排水区からなるとしてモデリングす る. ここに，単位排水区は，図-2 に示すように，上流 マンホール，一本の下水管渠およびその直接集水域から 構成されている.

なお，単位排水区の集水域面積，地表面における各種 流出面（和風屋根面，ビル屋根面，道路・駐車場面，小 規模な裸地面，大規模な裸地面）の諸量（面積, 斜面長, こう配，粗度など），また，上流マンホールおよび下水 管渠の諸元（直径，こう配，管渠長，段差など）は，い ずれも，基本的には，単位排水ごとに異なるとして取り 扱う。

\section{（2）雨水損失（有効降雨）モデル}

雨水損失の算定には, 修正 RRL 法において用いられ ている算定法6)を採用している.

まず, 前述した各種流出面を, 雨水損失の無い不浸透 流出面（和風屋根面）, 凹地損失のある不浸透流出面 （ビル屋根面, 道路面），凹地損失および浸透損失のあ る浸透流出面（小規模な裸地面，大規模な裸地面）の 3 種に分類する. 次に, 凹地損失は降雨が凹地を満たして 後に雨水流出がはじまるとして, また浸透損失は最終浸 透能を下回る強度分の降雨は全て浸透し，それを上回る 強度分の降雨が回地損失に充当されるとして取り扱う。

単位排水区内の平均有効降雨は, 3 種の流出面の有効 降雨をそれら流出面の占有面積率を重みとして加重平均 して求められる.

\section{（3）雨水流出モデル \\ a）地表面流出モデル}

ここでは, 上述した 3 種の流出面上の雨水 (有効降 雨）が単位排水区の上流マンホールに到達する時間（雨 水伝播時間あるいは雨水流入時間）が，時間的，空間的

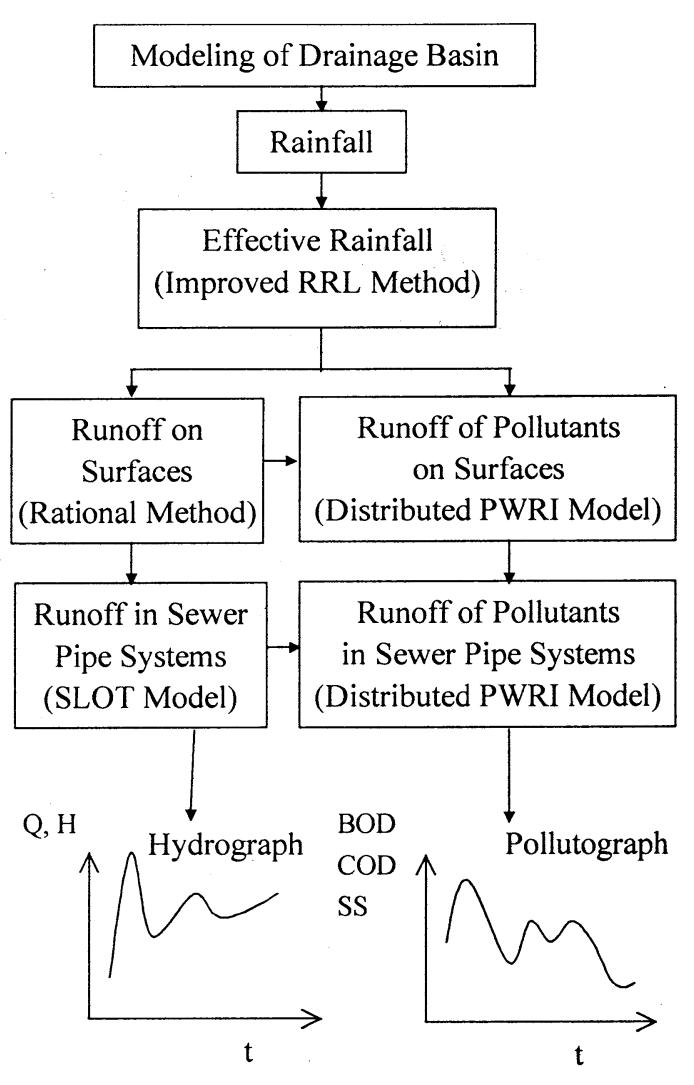

図-1 合流式下水道の雨天時污濁負荷流出解析モデル

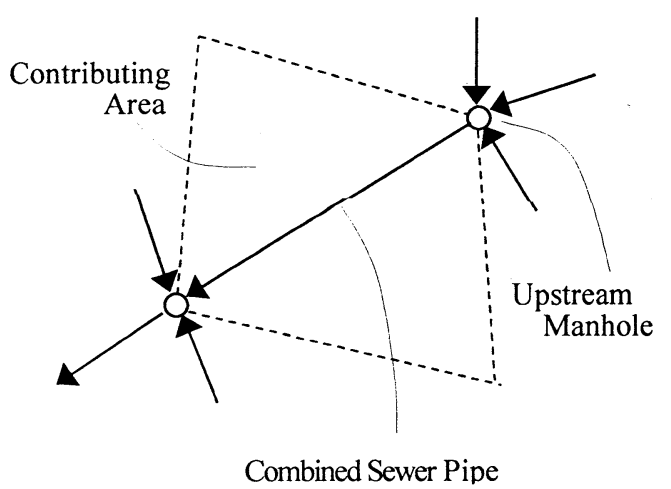

図-2 単位排水区

に一定（一様，5分）であるとし，合理式・合成法7)に より，マンホールへの流入ハイドログラフを算定する.

b) 管渠流出モデル

近年，下水道流域の雨水流出解析において，SWMM モデル, MOUSE モデル, Info Works モデルの 3 つの 海外モデルが広く用いられてきている.

ここでは，下水道管渠システムの雨水流出解析モデル として, MOUSE モデルの中の管渠流出モデルをそのま ま採用している. 


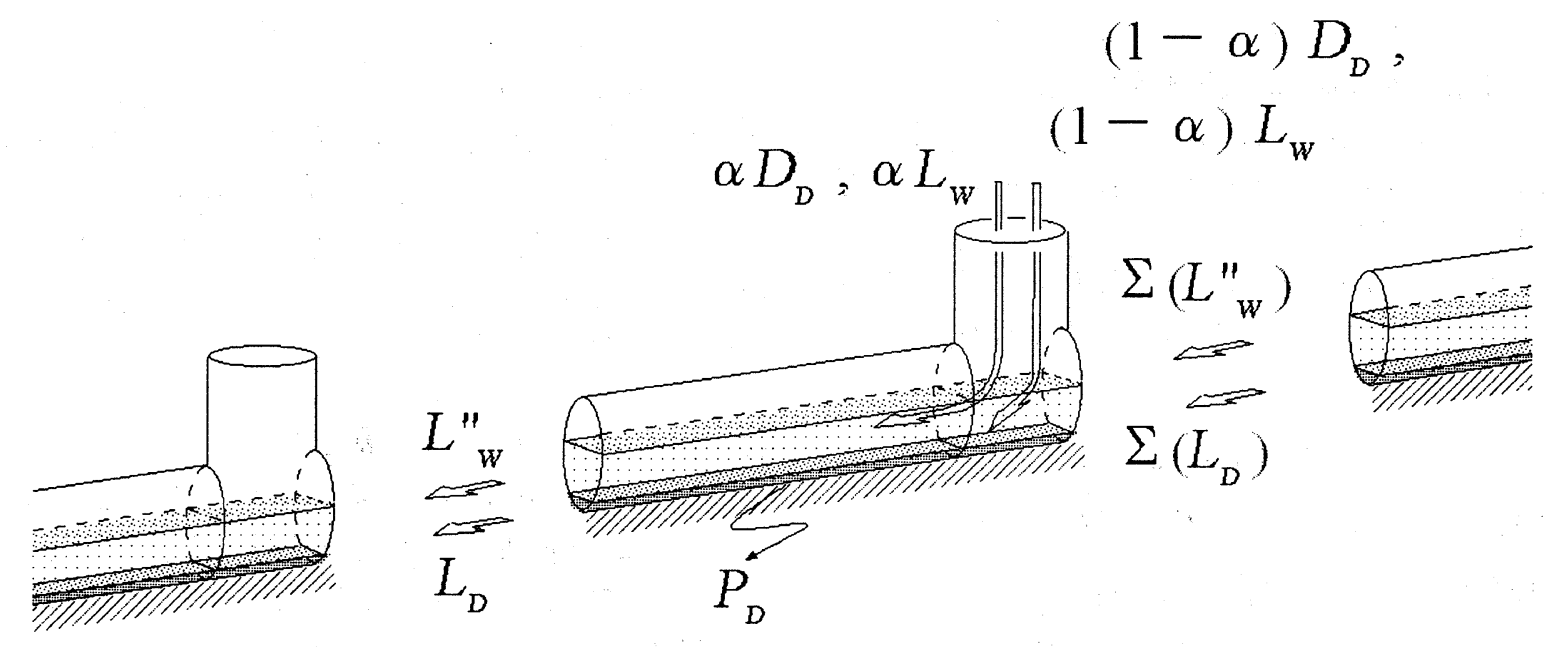

図-3 下水管渠における污濁負荷の流入出

（4）污濁負荷流出モデル

本モデルについては，次章で詳細を述べることとする．

\section{3. 污濁負荷流出解析モデル（分布型土研} モデル)

本モデルは，従来の土研モデル2）（集中型土研モデ ル）を分布型のモデルへと改良したもので, 図-1 に示 すように, 地表面污濁負荷流出解析モデルと下水道管渠 污濁負荷流出解析モデルからなる.

なお, 解析対象の水質項目は, 従来の土研モデルと同 様に, SS, BOD, COD の 3 つである. また, 污濁負 荷の発生場についても, 従来の土研モデルと同様に, COD と SS は地表面上と下水管渠内であるとして, 一 方，BOD は下水管渠内のみであるとして取り扱う.

\section{（1）污濁負荷流出の基礎式}

a）地表面上での污濁負荷流出モデル

分布型土研モデルでは, 集中型土研モデルにおいて流 域の地表面全体を対象に一括して適用されていた污濁負 荷の流出の式と連続の式を採用し，これら基礎式を各単 位排水区の各流出面に適用する.

これより，污濁負荷の流出の式および連続の式は，そ れぞれ，次式のように表される.

$\underline{\mathrm{COD}}$

$$
\begin{gathered}
L_{W C}=(1 / 3.6) C_{W C} P_{W C}^{\prime}\left(r_{e}-r_{e c}\right) A_{W} \\
d P_{W C} / d t=D_{W C}-L_{W C}
\end{gathered}
$$

$$
\begin{gathered}
; D_{W C}=1000 \times D_{W C}^{\prime} A_{W} \\
; P_{W C}=1000 \times P_{W C}^{\prime} A_{W}
\end{gathered}
$$

$\underline{\mathrm{SS}}$

$$
\begin{gathered}
L_{W S}=(1 / 3.6) C_{W S} P_{W S}^{\prime}\left(r_{e}-r_{e c}\right) A_{W} \\
d P_{W S} / d t=D_{W S}-L_{W S} \\
; D_{W S}=1000 \times D_{W S}^{\prime} A_{W} \\
; P_{W S}=1000 \times P_{W S}^{\prime} A_{W}
\end{gathered}
$$

ここに， $L_{W C} ， L_{W S}$ : 発生負荷量 $(\mathrm{gr} / \mathrm{s}), C_{W C}$, $C_{W S}$ : 負荷流出係数 $(1 / \mathrm{mm}), P_{W C}, P_{W S}$ : 滞積 (残 存）負荷量 $(\mathrm{gr}), P_{W C}^{\prime}, P_{W S}^{\prime}$ : 単位面積当りの滞積 負荷量 $(\mathrm{kg} / \mathrm{ha}) ， D_{W C} ， D_{W S}$ : 補給負荷量 $(\mathrm{gr} / \mathrm{s})$, $D_{W C}^{\prime}, D_{W S}^{\prime}$ : 単位面積当りの補給負荷量 $(\mathrm{kg} / \mathrm{s} / \mathrm{ha})$, $A_{W}$ : 降雨による污濁負荷発生に関与する流出面の面積 (ha),$r_{e}$ : 有効降雨強度 $(\mathrm{mm} / \mathrm{hr}), r_{e c}$ : 限界有効 降雨強度 $(\mathrm{mm} / \mathrm{hr}), t$ : 時間 $(\mathrm{s})$ ，第 1 下添字 $\mathrm{W}$ は流出面上（雨天時）に関する諸量であること, 第 2 下添字 C および S はそれぞれ COD および SS に関 する諸量であることを示す。

\section{b）下水管渠内での污濁負荷流出モデル}

分布型土研モデルでは，集中型土研モデルにおいて流 域の下水道管渠システム全体を対象に一括して適用され ていた污濁負荷の流出の式および連続の式を採用しここ れら基礎式を各単位排水区の各下水管渠（図-3）に適用 するとともに，污濁は掃流成分（粒子性污濁）と浮遊成 分（溶解性污濁）からなるとして取り扱う.

すなわち，図-3 に示寸ように，対象としている下水 
管渠の上流マンホール地点には，上流に位置する下水管 渠加ら流出污濁負荷, 直接集水域の流出面からの流出 污濁負荷および補給污濁負荷が流入することとなる．ま た，污濁の中で浮遊成分（溶解性污濁）の占める割合を $\alpha$ で表すこととする.

これより，下水管渠内における污濁負荷の流出の式と 連続の式は，それぞれ，次式のように表される.

BOD

$$
L_{B}=L_{D B}+L_{W B}^{\prime \prime}
$$

(掃流成分)

$$
; L_{D B}=C_{D B} P_{D B}{ }^{2}\left(Q-Q_{c}\right)
$$

(浮遊成分)

$$
; L_{W B}^{n}=Q \delta_{W B}
$$

(掃流成分)

$$
\begin{aligned}
& d P_{D B} / d t=\left(1-\alpha_{B}\right) D_{D B}-L_{D B} \\
& +\left(1-\alpha_{B}\right) L_{W B}+\sum\left(L_{D B}\right)
\end{aligned}
$$

(浮遊成分) $d\left(\forall \delta_{W B}\right) / d t=\alpha_{B} \cdot D_{D B}+\alpha_{B} \cdot L_{W B}$

$$
-Q \delta_{W B}+\sum\left(L_{W B}^{\prime \prime}\right)
$$

$\underline{\mathrm{COD}}$

(掃流成分)

$$
L_{C}=L_{D C}+L_{W C}^{\prime \prime}
$$

(浮遊成分)

$$
; L_{D C}=C_{D C} P_{D C}{ }^{2}\left(Q-Q_{c}\right)
$$

(掃流成分）

$$
; L_{W C}^{n}=Q \delta_{W C}
$$

(

$$
\begin{aligned}
& d P_{D C} / d t=\left(1-\alpha_{C}\right) D_{D C}-L_{D C} \\
& +\left(1-\alpha_{C}\right) L_{W C}+\sum\left(L_{D C}\right)
\end{aligned}
$$

(浮遊成分) $d\left(\forall \delta_{W C}\right) / d t=\alpha_{C} \cdot D_{D C}+\alpha_{C} \cdot L_{W C}$

$\underline{\mathrm{SS}}$

$$
-Q \delta_{W C}+\sum\left(L_{W C}^{\prime \prime}\right)
$$

（掃流成分） $; L_{D S}=C_{D S} P_{D S} Q\left(Q-Q_{c}\right)$

（浮遊成分） $\quad ; L_{W S}^{\prime \prime}=Q \delta_{W S}$

(掃流成分) $d P_{D S} / d t=\left(1-\alpha_{S}\right) D_{D S}-L_{D S}$

$$
+\left(1-\alpha_{S}\right) L_{W S}+\sum\left(L_{D S}\right)
$$

(浮遊成分） $\quad d\left(\forall \delta_{W S}\right) / d t=\alpha_{S} \cdot D_{D S}+\alpha_{S} \cdot L_{W S}$

$$
-Q \delta_{W S}+\sum\left(L_{W S}^{\prime \prime}\right)
$$

ここに, $\alpha_{B}, \alpha_{C}, \alpha_{S}$ : 浮遊成分の存在割合を示 寸係数 $(0 \leq \alpha<1), L_{B}, L_{C}, L_{S}$ : 掃流成分と浮 遊成分を合わせた発生污濁負荷量 $(\mathrm{gr} / \mathrm{s}), L_{D B}, L_{D C}$, $L_{D S}$ : 掃流成分としての発生污濁負荷量 $(\mathrm{gr} / \mathrm{s}), P_{D B}$, $P_{D C}, P_{D S}$ : 掃流成分としての滞積負荷量 $(\mathrm{gr})$, $C_{D B}, C_{D C}, C_{D S}$ : 污濁負荷流出係数 $\left(1 / \mathrm{gr} / \mathrm{m}^{3}\right.$, $\left.1 / \mathrm{gr} / \mathrm{m}^{3}, \mathrm{~s} / \mathrm{m}^{6}\right), D_{D B}, D_{D C}, D_{D S}$ : 補給污濁負荷 量 $(\mathrm{gr} / \mathrm{s}), \sum\left(L_{D B}\right), \sum\left(L_{D C}\right), \sum\left(L_{D S}\right)$ : 上 流管渠よりの掃流成分としての流入污濁負荷量の合計 $(\mathrm{gr} / \mathrm{s}), L_{W B}^{\prime \prime}, L_{W C}^{\prime \prime}, L_{W S}^{\prime \prime}$ : 浮遊成分としての発生 污濁負荷量（gr/s）， $\sum\left(L_{D B}^{\prime \prime}\right) ， \sum\left(L_{D C}^{\prime \prime}\right)$, $\sum\left(L_{D S}^{\prime \prime}\right)$ : 上流管渠よりの浮遊成分としての流入污濁 負荷量の合計, $\delta_{W B}, \delta_{W C}, \delta_{W S}$ : 浮遊成分の下水管 管渠内における濃度 $(\mathrm{mg} / \mathrm{l}), Q$ : 計算流量 $\left(\mathrm{m}^{3} / \mathrm{s}\right)$, $Q_{c}$ : 限界流量 $\left(\mathrm{m}^{3} / \mathrm{s}\right), \forall$ : 下水管渠内の貯留水量 $\left(\mathrm{m}^{3}\right)$, である.

\section{（2）モデル・パラメータの算定法}

各下水管渠に対する污濁負荷流出係数 $C_{D B}, C_{D C}$, $C_{D S}$ および初期滞積污濁負荷量 $P_{D B, 0}, P_{D C, 0}$, $P_{D S, 0}$ の算定法，ならびに各流出面に対する污濁負荷 流出係数 $C_{W C}, C_{W S}$ および初期滞積負荷量 $P_{W C, 0}$, $P_{W S, 0}$ の算定法は，いずれも，既に ${ }^{4)}$ 述べてきている ので，ここでは省略する.

なお，浮遊成分の存在割合を示寸係数 $\alpha$ の算定法 については，現段階では，経験的に適值を見出すことに なる.

\section{4. 分布型土研モデルの実流域への適用性に関}

\section{する検討}

上述した污濁負荷流出解析モデル（分布型土研モデ ル）を，低平市街地の一つの合流式ポンプ排水区に適用 し, 降雨時の雨水と水質の流出シミュレーション結果を 実測結果と対比して, 本解析法（分布型土研モデル）の 実流域への適用性について検討した.

\section{(1) 解析対象排水区の概要}

解析対象排水区は，図-4 および図-5 に示すように， 集水面積が $45.5 \mathrm{ha}$ ，不浸透域が排水区の $85 \%$ を占め る典型的な市街地域（商業地域）である.

下水道管渠システムは, 直径が $300 \sim 1800 \mathrm{~mm}$, 総延 長がおよそ $10 \mathrm{~km}$ の下水管渠からなり,こう配は 4 0/00（平均）と全体に緩やかである．また，低平地であ ることに加え，下流端のポンプ場での吐出ポンプが間欠 的に運転されているため, 降雨時には, 下水道管渠シス テム内で，せき上げ背水や低下背水現象が生じていると 考えられ, さらに, 強雨時には, 圧力流れ（満管流れ） などを伴うサーチャージ現象も生じていると考えられる.

\section{（1）流出シミュレーション結果}

提案した雨天時污濁負荷流出解析モデル（土研モデ ル）を上述したポンプ排水区に適用し，本モデルによる 雨水と污濁負荷の流出シミュレーション結果を実測結果 


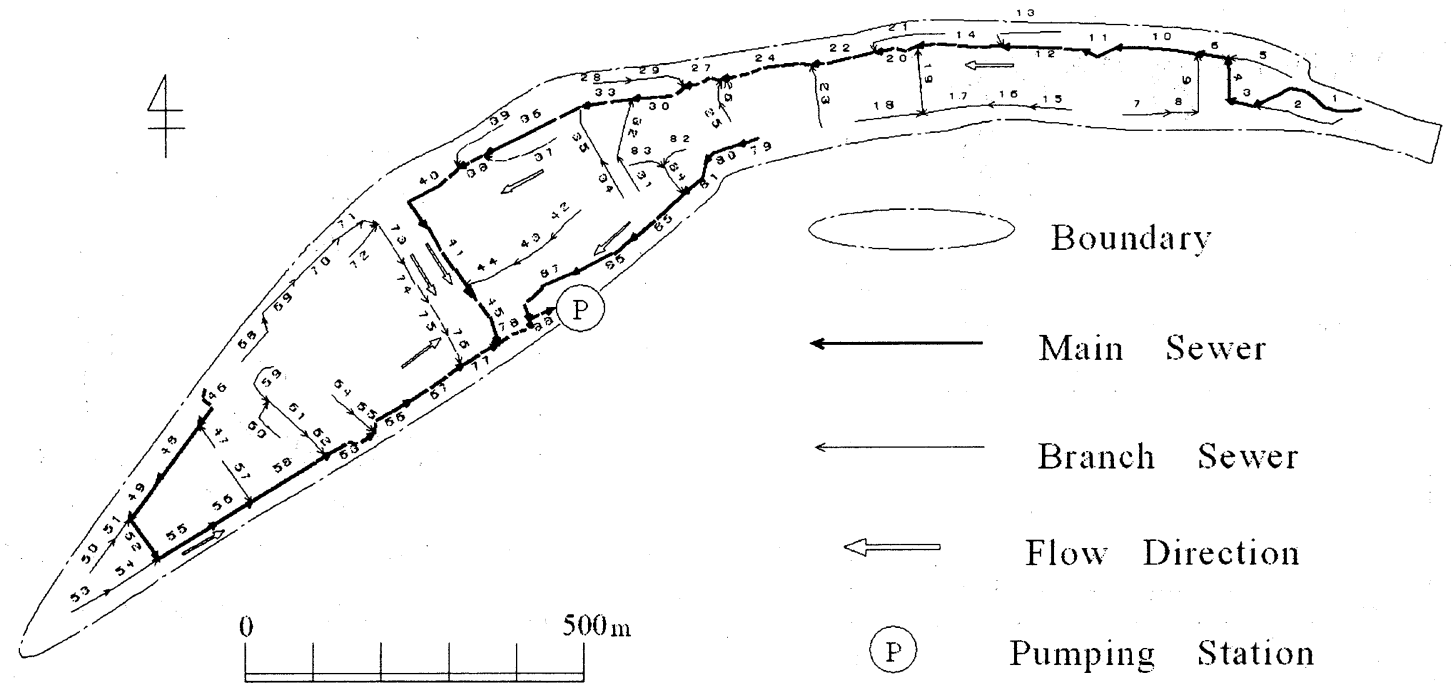

図-4 解析対象排水区とその下水管渠システム

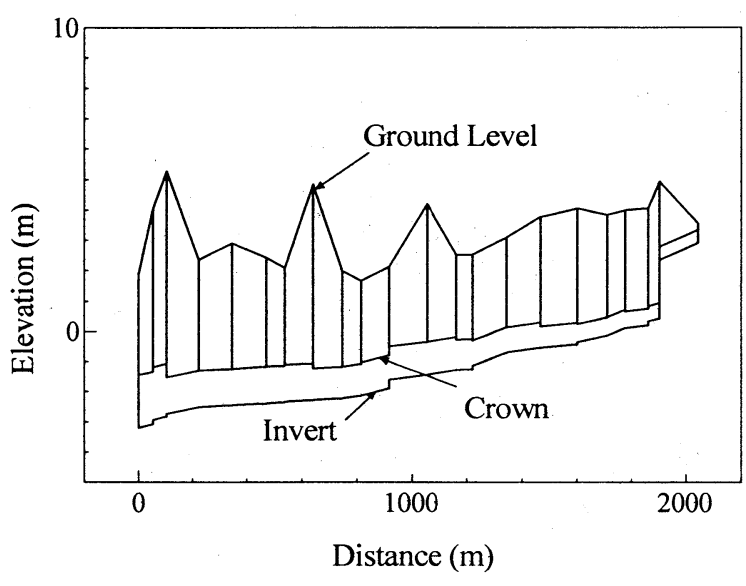

図-5 幹線下水管渠システムの縦断図

表-1 各下水管渠における SS に関するパラメータの適値

\begin{tabular}{|c|c|c|}
\hline & $\begin{array}{c}\mathrm{P}_{\mathrm{DS}, 0} \\
(\mathrm{~kg})\end{array}$ & $\begin{array}{c}\mathrm{C}_{\mathrm{DS}} \\
\left(\mathrm{s} / \mathrm{m}^{6}\right)\end{array}$ \\
\hline$\alpha_{\mathrm{S}}=0.0$ & $1.5 \sim 15.0$ & $0.02 \sim 100.0$ \\
\hline$\alpha_{\mathrm{S}}=0.5$ & $1.5 \sim 15.0$ & $0.15 \sim 55.0$ \\
\hline
\end{tabular}

と対比して，本モデルの実流域への適用性について検討 した. 検討結果の一例（SS-流出）を，表-1，図-6〜-10 に示す.ここに，地表面における初期滞積負荷量は455 $\mathrm{kg}$ ，下水管渠システム全体でのそれは628 kg である.

これらより，次の諸点が指摘される. (1) $\alpha_{\mathrm{s}}$ 值の違い により，污濁負荷の流出特性はかなり異なってきており

(図-9 および -10)， $\alpha_{\mathrm{s}}$ が重要なパラメータであるこ とが分かる. (2) 初期滞積負荷量は, 下水管渠ごとに異 なり，概ね，表-1 に示す範井の值となっている. (3) 污 濁負荷流出係数の適值は，下水管渠ごとに異なり，概ね, 表-1 に示す範囲の值となっている. (4) 分布型土研モデ ルによる污濁負荷の流出シミュレーション結果（図-9,

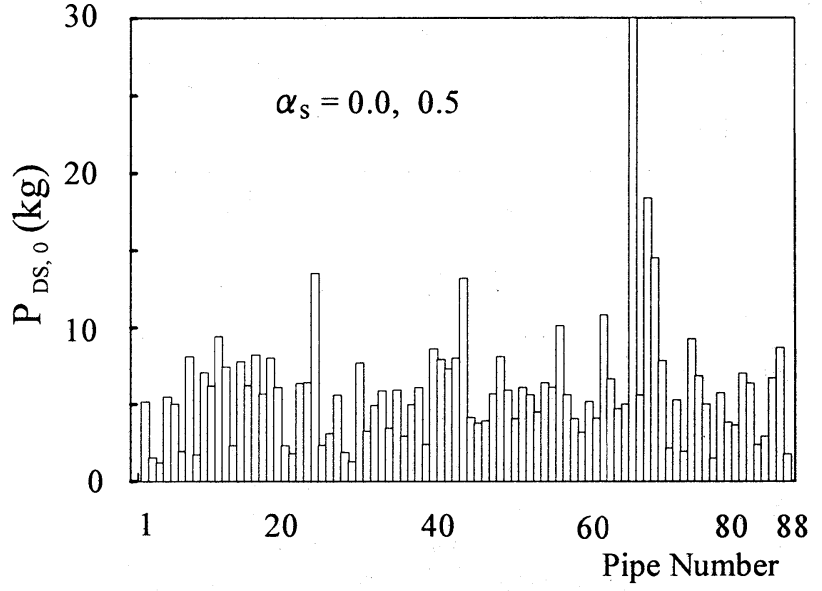

図-6 各下水管渠（88 本）における初期滞積負荷量

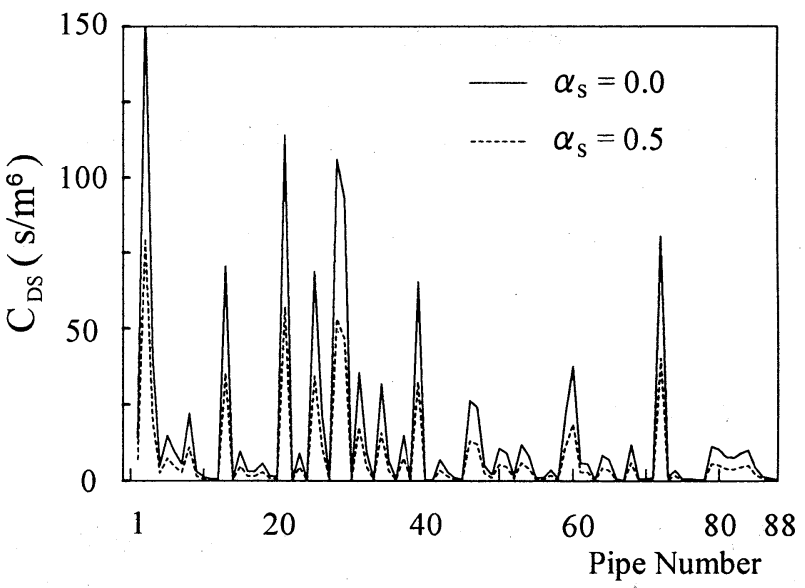

図-7 各下水管渠 (88 本) における污濁負荷流出係数の適值

-10）を見ると，流出の後半で，下水管渠内の残存負荷 量が低下して污濁負荷流出が小さくなり, かなりの精度 低下を来しているが，全体的には，実用上の精度で実測 結果を再現しえている結果の得られていることが分かる. 


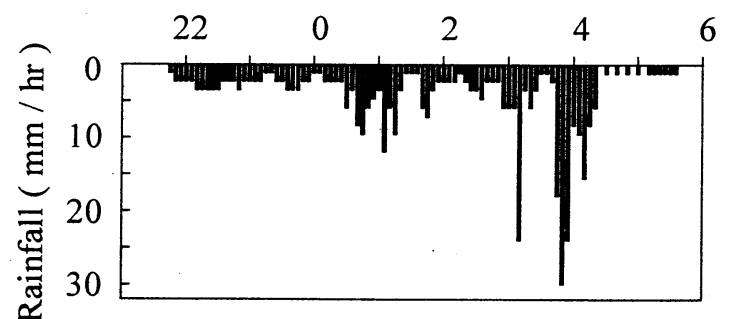

（a）ハイエトグラフ（実測）

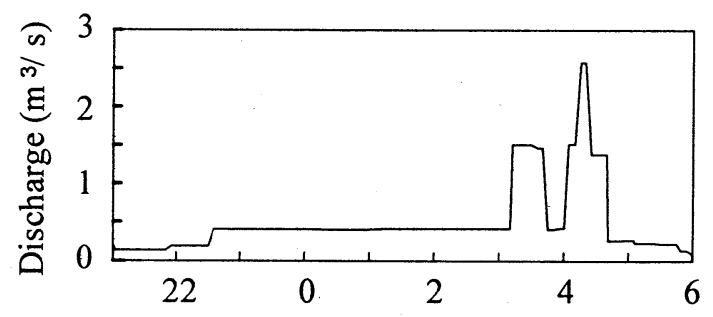

(b) ポンプ吐出流量ハイドロ（実測）

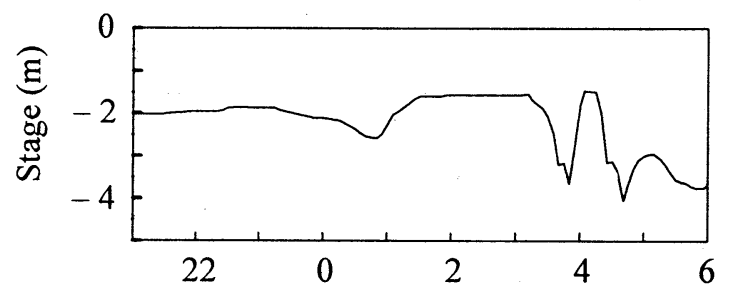

（c）ポンプ井水位ハイドロ（実測）

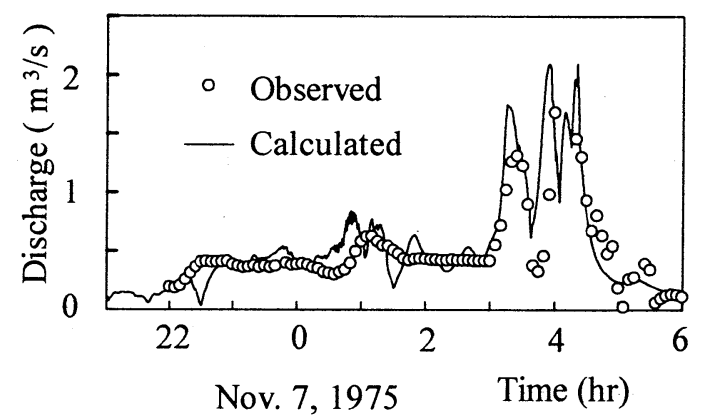

（d）流量ハイドロの計算結果と実測結果の比較

図-8 流出シミュレーション結果

\section{4. おわりに}

本論文では，溶解性（浮遊型）と粒子性（掃流型）の 污濁を取り扱うことができる分布型土研モデルを提案す るとともに，その実流域一の適用性について実証的立場 から検討を進めてきた.

その結果，本土研モデルを用いれば，合流式下水道の 雨天時污濁負荷流出を精度高くシミュレートしえるであ ろう見通しが得られた。

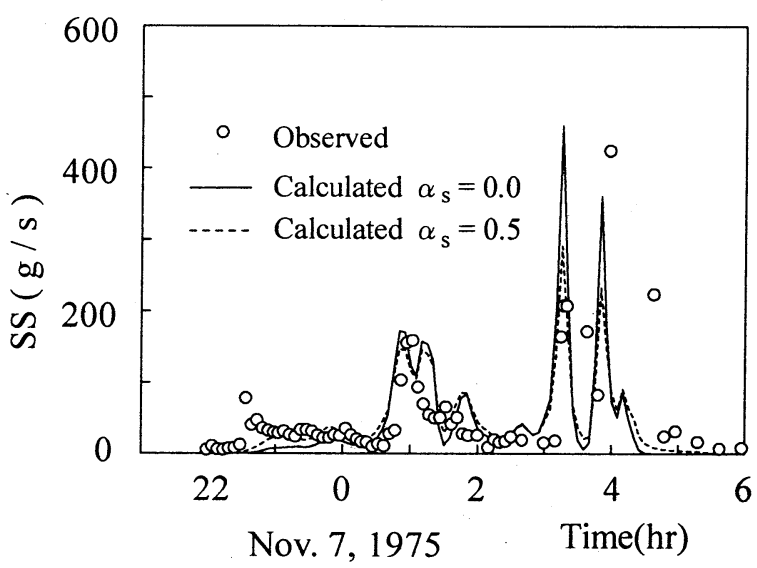

図-9 流出シミュレーション結果 (SS-ロードグラフ)

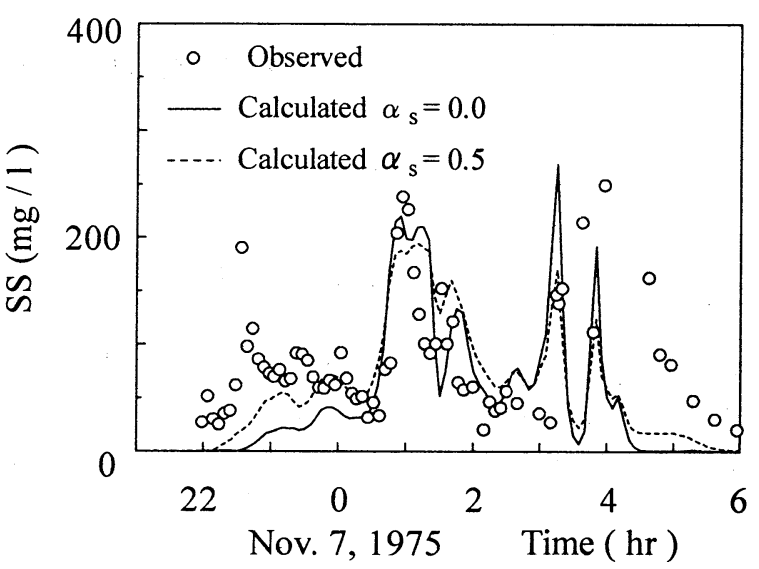

図-10 流出シミュレーション結果（SS-ポルート グラフ)

1) (財)下水道新技術推進機構 : 流出解析モデル利活用マニュア ル（雨水対策における流出解析モデルの運用手引き）, pp.

2) (社) 日本下水道協会: 合流式下水道己褰対策指針之解説 -2002年版一, pp. 376 383， 2002.

3) 渡辺政広, 永吉光一, 岡田将人 : 合流式下水道流域におけ る雨天時污濁負荷流出の分布型非定常解析モデル，環境工 学研究論文集, 第35巻, pp. 73〜84, 1998.

4) 渡辺政広, 永吉光一, 右近雄大: 土研モデルとSWMMを組 み合わせた下水道流域の污濁負荷流出モデル，水工学論文 集, 第42巻, pp. 199〜204， 1998.

5) 渡辺政広, 西村文武, 重田尚秀, 小林康司: 都市流域の不 浸透流出面（屋根面，道路面）における雨水・污濁負荷流 出特性，水工学論文集，第45巻，pp. 55 60, 2001.

6) 山口高志, 松原重昭, 山守 隆: 都市における降雨流出調 查第2報一修正RRL法による流出推定一, 土木技術資料，第 14巻第11号, pp. 34〜39, 1972.

7) (社)日本下水道協会 : 下水道雨水調整池技術基準(案)一解説 と計算例一, pp. 8〜18, 1984. 